\title{
Valorization of Fish Waste Compost as a Fertilizer for Agricultural Use
}

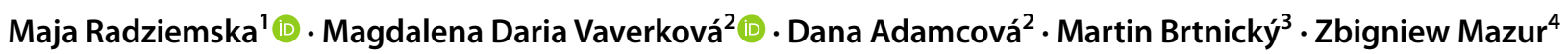

Received: 17 November 2017 / Accepted: 31 March 2018 / Published online: 16 April 2018

(c) The Author(s) 2018

\begin{abstract}
The manuscript presents results of the evaluation of compost from fish waste (FW) as a fertilizer for agricultural use. A pot experiment was conducted to compare the effects of compost from FW on the yield and macro and microelemental composition of ice lettuce (Lactuca sativa L.). In addition, the phytotoxicity degree of the compost and compost effects on seed germination and primary root growth were determined with white mustard (Sinapis alba L.). Compost used in the study consisted of FW and pine bark. Results of the evaluation enable concluding that the compost from FW is non-phytotoxic, mature, stable, and suitable for use in agriculture. Its addition to soil caused an increase in fresh and dry matter yield of leaves of ice lettuce (L. sativa L.). Fertilization had a significant effect on increased contents of nitrogen, phosphorus, potassium, sodium, calcium, and magnesium in leaves of the test plant. The average accumulation of microelements in ice lettuce (L. sativa L.) grown in the soil fertilized with compost from $\mathrm{FW}$ followed the descending order $\mathrm{Fe}>\mathrm{Cu}>\mathrm{Ni}>\mathrm{Zn}>\mathrm{Mn}$, respectively. Soil fertilization with compost from FW improved the $\mathrm{K}:(\mathrm{Mg}+\mathrm{Ca}), \mathrm{K}: \mathrm{Mg}$ and $\mathrm{K}: \mathrm{Ca}$ ratios but, simultaneously, deteriorated the $\mathrm{Ca}: \mathrm{P}$ ratio.
\end{abstract}

\section{Graphical Abstract}

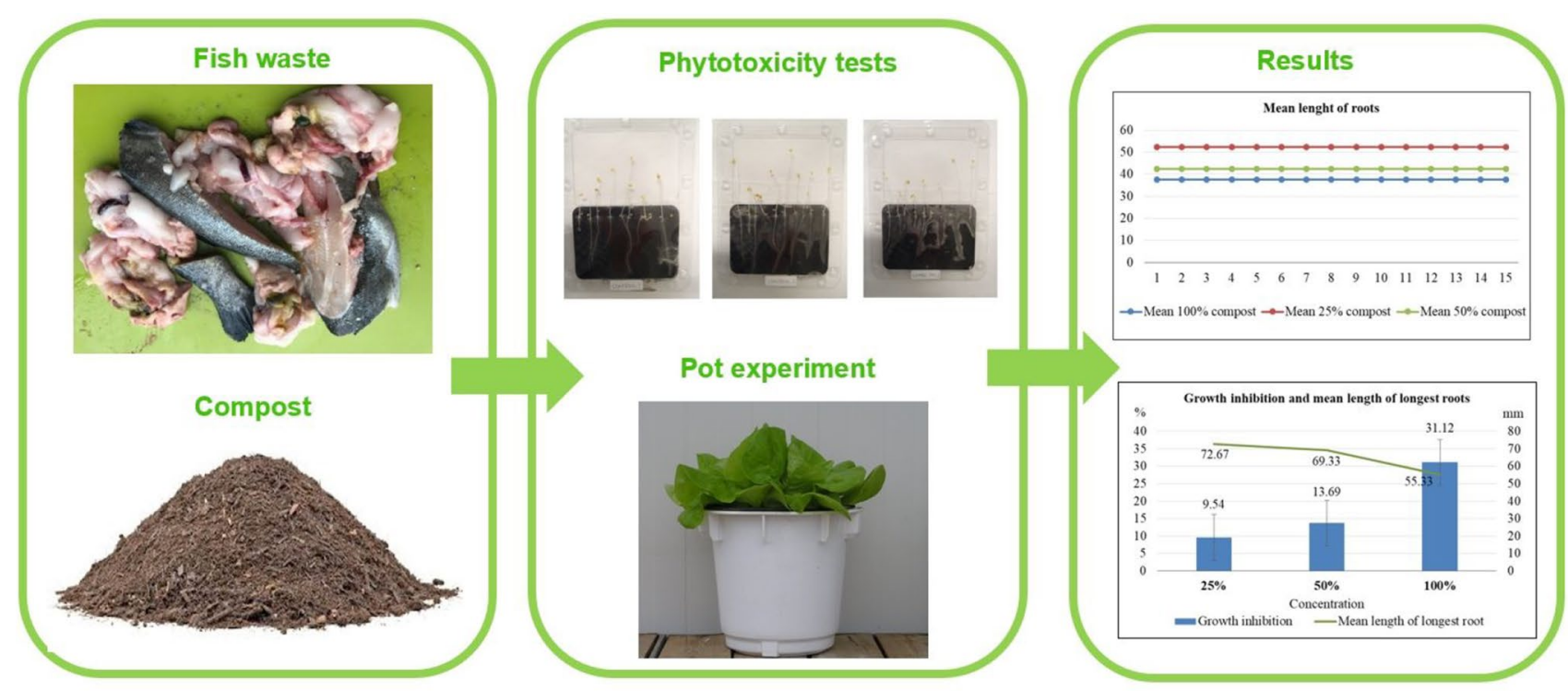

Keywords Composting · Fish waste · Toxicity of compost · Organic fertilizer · Sinapis alba L. · Lactuca sativa L.

Zbigniew Mazur

zbigniew.mazur@uwm.edu.pl

Extended author information available on the last page of the article 


\section{Introduction}

Directive 2008/98/EC was adopted to introduce a new approach to the handling of waste and its management. Worldwide solid waste (SW) is an important and emerging environmental problem [1]. Accordingly, the Waste Framework Directive (WFD) and hierarchy priorities the prevention of waste generation, followed by processing for reuse and recycling, with disposal as the least favored stage of waste management (WM). Food waste was considered a special case in the WFD, focusing on three key points: the separate collection of bio-waste, treatment of bio-waste to ensure maximum environmental protection (composting and digestate), and the development of techniques to produce environmentally safe materials from bio-waste [2]. Food waste comprises the main fraction (45\%) of total municipal solid waste (MSW) in Europe [3]. Sustainable management of food waste is a momentous research area that has rapidly grown over recent years [4]. Worldwide there are several techniques for waste processing into value-added products in the form of compost (organic fertilizer), biogas, animal feed and chemicals [5]. Composting is a natural process [6], an eco-friendly biochemical technique, and a viable alternative for a sustainable MSW management [7].

The Regulation (EC) of the European Parliament and the Council on health rules concerning animal by-products not intended for human consumption describes products derived from aquatic animals, including fish, as removed e.g. by incineration or co-incineration, fermentation, composting or transformation into biogas [8]. Fish waste (FW) can be suitable material for composting. One such material is, which is yielded as a by-product of fish production and fish processing industries. Depending on the type of transformation, the waste may represent between 30 and $45 \%$ of the initial weight of the product [9].

FW is suitable for agricultural use owing to high contents of nutrients, such as N, P, and Ca [9]. Several fertilizers made of fishmeal are now commercially available and some are authorized for use in organic agriculture [10]. Even fish effluent can be used to irrigate cherry tomato plants [9, 11]. Composting initiatives using FW have been carried out in various parts of the world in search of alternative and viable techniques for transforming fish waste into useful agricultural products [12].

Considering the benefits of composting, the composting itself is a biotransformation process of organic materials into stable and complex macromolecules under the action of microorganisms including fungi, bacteria, and corresponding enzyme(s) [13-15]. It includes four phases: (i) an initial decomposition phase; (ii) a thermophilic phase of intense microbial decomposition; (iii) the second thermophilic phase; and (iv), a maturation phase. Rapidly multiplying thermophilic bacterial species dominate during the thermophilic phase till the moment when the bulk of the easily decomposable substrate is exhausted. The majority of the remaining material is woody with lignin as the dominating part, which is also stabilized by humic acids and fungi $[15,16]$. The final product, compost, can be used as a soil amendment that improves soil texture and fertility and thus reduces the use of synthetic fertilizers applied to the soil. In this case, the conversion should be performed by implementation of novel technologies for the recycling of waste in the form of compost for their use in agriculture [17]. In addition to the usage of compost as a fertilizer, applying compost to the soil may increase the carbon storage capacity within the soil, which reduces greenhouse gas (GHG) emissions into the atmosphere [3, $18,19]$.

The above-mentioned material is of great potential use in agriculture. However, its stabilization is recommended prior to its use to prevent problems associated with the appearance of phytotoxic substances $[9,20]$. When compost is land applied, finished compost with no phytotoxin can be regarded as a source of nutrients to improve soil structural properties and accelerate germination. Therefore, assessing the phytotoxicity degree of the compost products is essential to achieve high quality compost [21].

The aim of the present paper was to assess the fertilizing power of compost consisting of FW and pine bark. The phytotoxicity degree of the compost and effects of the compost on seed germination and primary root growth were determined with white mustard (Sinapis alba L.). Additionally, the effect of the compost application on ice lettuce (Lactuca sativa L.) was determined. The authors hypothesized that FW compost might be a suitable for agricultural use.

\section{Materials and Methods}

Compost used in the experiment was prepared from $(\mathrm{w} / \mathrm{w})$ $80 \% \mathrm{FW}$ and $20 \%$ pine bark (10-15 mm chip size) as a bulking agent and carbon source with the following composition: organic carbon $-566.2 \pm 7.3$ (g/kg d.m.), total $\mathrm{N}-1.92 \pm 0.1$ (g/kg d.m.), phosphorous $-0.40 \pm 0.1$ (g/kg d.m.), potassium $-0.94 \pm 0.1$ (g/kg d.m.), magnesium $-1.12 \pm 0.1$ (g/ $\mathrm{kg} \mathrm{d.m}$.), and calcium $-1.22 \pm 0.1$ (g/kg d.m.). Contents of macro- and micro-elements in compost dry matter were presented in Table 1.

\section{Phytotoxicity Test}

Maturity and toxicity of the compost were determined to establish its usability for agricultural purposes. The seeds of white mustard ( $S$. alba L.) were used in a seed germination 
Table 1 Chemical composition of fish waste compost, in dry matter

experiment to assess the phytotoxicity [22] of the final compost [23]. The Phytotoxkit makes use of flat and shallow transparent test plates composed of two compartments, the lower one which contains soil saturated to the water holding capacity. The phytotoxkit measures the decrease (or the absence) of seed germination and of the growth of young roots after 3 days of the exposure of selected seeds of higher plants to a contaminated matrix, in comparison to the controls in a reference soil. Water saturation is calculated according to the user's manual. Distilled water was spread over the entire surface of the soil in the test plate. Ten seeds of $S$. alba L. were positioned at equal distances near the middle ridge of the test plate on a filter paper placed on the top of the hydrated soil/compost mixture. After closing, the test plates were placed vertically in a holder and incubated at $25^{\circ} \mathrm{C}$ for 3 days. At the end of the incubation period a digital picture was taken of the test plates with the germinated plants. The following concentrations of compost were tested in three replications: 25,50 , and $100 \%$. The analyses and the length measurements were performed using the Image Tool 3.0 for Windows (UTHSCSA, San Antonio, USA). The bioassays were performed in three replicates [24].

\section{Pot Experiment}

The fertilizing efficiency of the compost was assessed by its application to ice lettuce (L. sativa L.) crop. Tests using plants such as L. sativa L., present several advantages. Firstly, these tests are simple, quick, and reliable. Secondly, they are inexpensive and do not require major equipment. Thirdly, plants can be more sensitive to environmental stress over other organisms [25]. The vegetation pot experiment was conducted at a steady temperature of $22 \pm 2{ }^{\circ} \mathrm{C}$ in the greenhouse facility of the University of Warmia and Mazury in Olsztyn (Poland). The pots were maintained under natural day/night conditions; during the day (14 h), with a relative humidity of $75 \pm 5 \%$. Soil used in the experiment was obtained from the arable layer $(0-20 \mathrm{~cm})$ of a farm field. PCV pots filled with $10 \mathrm{~kg}$ of soil that had been previously mixed with the compost in accordance with the study procedure were used for this purpose. The soil used in the experiment was characterized by a $\mathrm{pH}$ value of 5.7 and granulometric composition of $86 \%$ sand $(2.0-0.05 \mathrm{~mm})$, $11.2 \%$ dust $(0.05-0.002 \mathrm{~mm})$, and $2.2 \%$ content of fractions under $0.002 \mathrm{~mm}$ in diameter ( $\mathrm{S}$ according to USDA). The content of organic carbon and nitrogen in this soil was: Corg. $-6.33 \mathrm{~g} / \mathrm{kg}, \mathrm{N}$-total $-0.55 \mathrm{~g} / \mathrm{kg}$, absorbable elements: phosphorus $-84.86 \mathrm{mg} / \mathrm{kg}$, magnesium $-77.48 \mathrm{mg} / \mathrm{kg}$, and potassium $-57.89 \mathrm{mg} / \mathrm{kg}$ soil. The soil samples were airdried and passed through a 5-mm sieve prior to the greenhouse pot experiment.

The experiment was conducted in four replicates. Compost was applied in the amount of $2 \mathrm{~g} \mathrm{~N}$ compost per pot. Non-fertilized pots served as control objects. The effect of fertilizations was tested on ice lettuce (L. sativa L.) of the Dobra variety. The density was one plant per pot. During the vegetation, soil humidity was maintained at the level of $60 \%$ capillary water capacity. The lettuce was picked upon reaching full maturity (after 51 days of vegetation).

\section{Analytical Methods}

Compost samples were mineralized in concentrated sulfuric(VI) acid with hydrogen peroxide added as a catalyst. After mineralization of the compost samples, the content of phosphorus and potassium was analyzed with the vanadium-molybdenum method, and that of calcium and sodium with atomic emission spectroscopy-AES on FLAPHO 4 CZJ model. Magnesium content was assayed with atomic absorption spectroscopy-AAS and that of total nitrogen using Kjedahl's method.

The contents of micronutrients: copper, cadmium, chromium, lead, nickel, and zinc were determined in an air-acetylene flame, following the flame atomic absorption spectrophotometric method (FAAS) on a SpecrtAA 240FS atomic absorption spectrophotometer (VARIAN, Australia) using a Sample Introduction Pump System (SIPS) in extracts obtained after microwave digestion of compost samples in nitric acid hydrogen (analytically pure $\mathrm{HNO}_{3}$ ) at a concentration of $1.40 \mathrm{~g} / \mathrm{cm}$, poured into HP500 Teflon vessels and placed in an MARS-5 microwave oven (CEM Corporation, USA). The mineralization conditions, i.e. volume of nitrogen acid and mineralization temperature, were set as described in the methodology given in the Mars 5 Operation Manual (2001). Compost samples were digested and analyzed using the same reagents. Double deionized water (Milli-Q Millipore $0.055 \mu \mathrm{S} / \mathrm{cm}$ resistivity) was used for all dilutions. Organic carbon content of compost was determined with 
the method of non-dispersive infrared (NDIR) spectrometry using a TOC-VCPN analyzer with an SSM-5000A module for carbon content assay in solid samples by Shimadzu.

\section{Calculations and Data Analysis}

The percent inhibition of root growth (RI) were calculated as follows $[24,26]$ :
Figure 2 presents results of measurements of root length of plants grown in soil fertilized with a $25 \%$ dose of compost for all three replicates. This concentration of compost stimulated root growth of white mustard ( $S$. alba L.) seeds and ensured the highest values of root elongation (of all compost concentrations analyzed). The mean root length was $52.27 \mathrm{~mm}$.

Further analyzed were the samples of plants grown in

$\mathrm{RI}(\%)=\frac{\text { (Mean root length in the control }- \text { Mean root length in the test })}{(\text { Mean root length in the control) }} \times 100$

GI $(\%)=(\%$ Seed germination $) \times(\%$ Root elongation $) / 100$

The results were subjected to statistical calculations using the Statistica 10 software package [27] (StatSoft Inc. 2010), with results of each series subjected to statistical analysis using Tukey's analysis of variance. The series were compared with the $t$ test for dependent variables, assessing differences between the average results.

\section{Results and Discussion}

At the end of the 3-day toxicity bioassay-Phytotoxkit ${ }^{\mathrm{TM}}$ (Fig. 1), the length of roots was measured in particular test plants grown in soil with various concentrations of the compost from FW.

Fig. 1 Phytotoxicity test in laboratory conditions - the experiment setup soil fertilized with $50 \%$ dose of the fish compost. Figure 3 depicts length of roots of test plants grown at this compost concentration for all three replications. At this concentration of compost, roots of test plants were shorter compared to root lengths determined at compost concentration of $25 \%$. The mean root length reached $42.42 \mathrm{~mm}$ and was, on average, by $9.85 \mathrm{~mm}$ lesser than in the samples grown at compost concentration of $25 \%$.

The toxicity symptoms become severe with the increased dose of compost. Figure 4 presents the mean root length of plants grown at $100 \%$ compost concentration, which was significantly lower compared to plants fertilized with 25 and $50 \%$ of compost. The mean root length accounted for $37.56 \mathrm{~mm}$ and was lower by $14.71 \mathrm{~mm}$ and by $4.86 \mathrm{~mm}$ than in plants grown at 25 and $50 \%$ compost concentration.
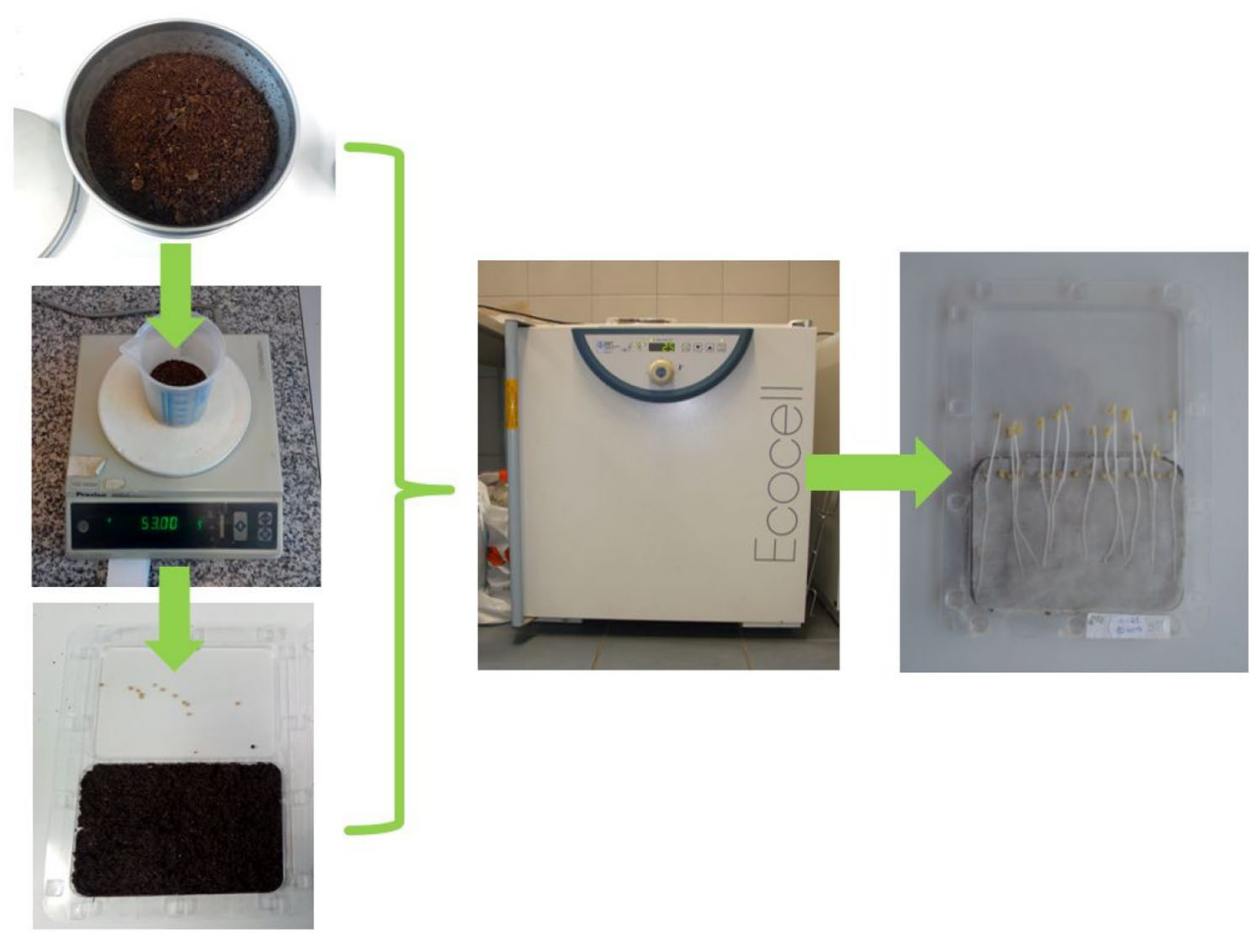
Fig. 2 Length of roots at compost concentration of $25 \%$

Fig. 3 Length of roots at compost concentration of $50 \%$

Fig. 4 Length of roots at compost concentration of $100 \%$

$$
\begin{array}{r}
\mathrm{mm} \\
80 \\
70 \\
60 \\
50 \\
40 \\
30 \\
20 \\
10
\end{array}
$$

0

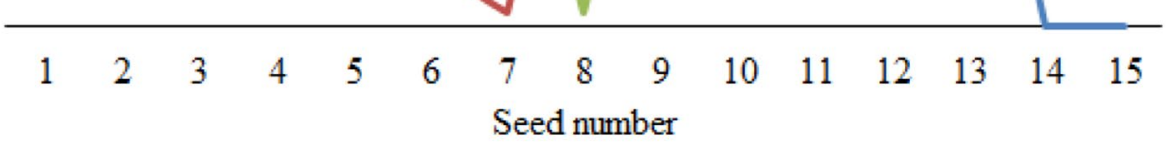

$-25 \% \mathrm{~A}-25 \% \mathrm{~B}-25 \% \mathrm{C}-$ Mean $\mathrm{ABC}$

$\mathrm{mm}$

Length of roots $-50 \%$ compost

80

70

60

50

40

30

20

10

0

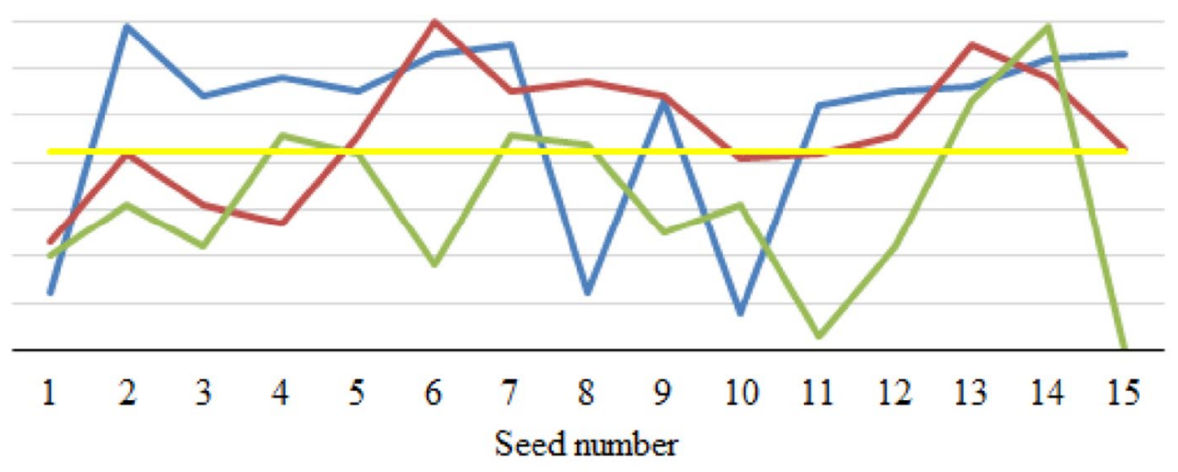

$-50 \% \mathrm{~A}-50 \% \mathrm{~B}-50 \% \mathrm{C} \longrightarrow$ Mean $\mathrm{ABC}$

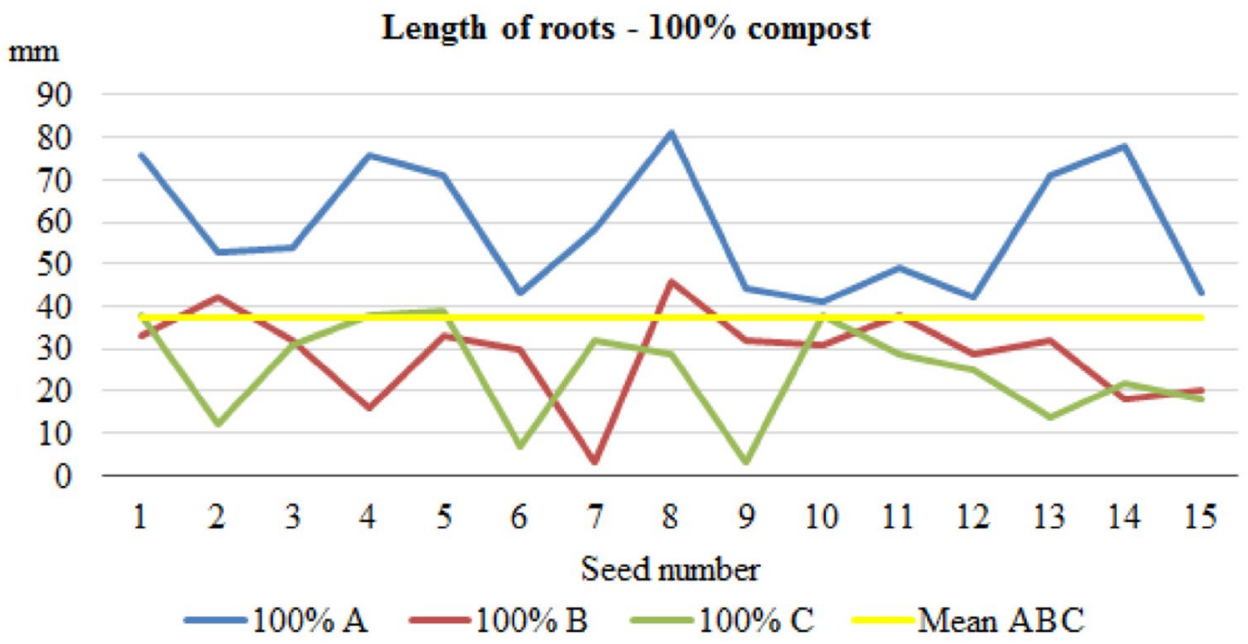




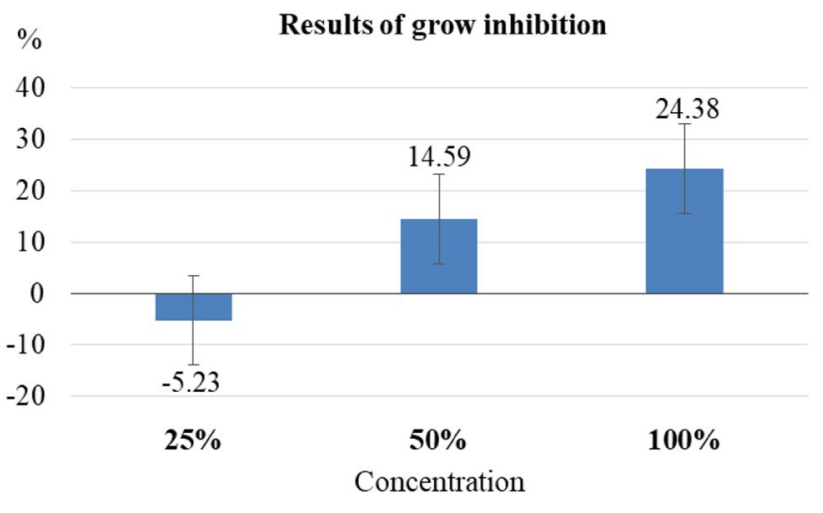

Fig. 5 Root growth inhibition at various compost concentrations

Table 2 Effect of fish compost application on the fresh and dry matter yield of leaves of ice lettuce (Lactuca sativa L.)

\begin{tabular}{|c|c|c|c|c|}
\hline \multirow[t]{2}{*}{ Fertilization } & \multicolumn{2}{|l|}{ Fresh matter } & \multicolumn{2}{|l|}{ Dry matter } \\
\hline & $\mathrm{g} /$ per pot & $\begin{array}{l}\text { Relative to } \\
\text { control \% }\end{array}$ & $\mathrm{g} /$ per pot & $\begin{array}{l}\text { Relative } \\
\text { to control } \\
\%\end{array}$ \\
\hline Control* & $44.87 \pm 4.01 \mathrm{a}$ & 100 & $8.11 \pm 0.77 \mathrm{a}$ & 100 \\
\hline Compost & $86.65 \pm 10.11 b$ & 193.11 & $11.84 \pm 1.21 \mathrm{~b}$ & 145.99 \\
\hline
\end{tabular}

Bars marked with different letters differ significantly $(P<0.05)$ according to Duncan's test

Mean values of four replicates ( \pm standard deviation) are shown in the table. Data within columns that do not have common indices are significantly different at $\mathrm{p}<0.05$

$*$ Without fertilization

Afterwards, root growth inhibition was computed for particular compost concentrations and respective results were presented in Fig. 5. Compost concentration of $25 \%$ had a stimulating effect on root growth and caused root elongation by $5.23 \%$, whereas the other two compost doses inhibited root growth by $13.69 \%$ (50\% compost) and $31.12 \%(100 \%$ compost).

The germination index (GI) is a factor of relative seed germination and relative root elongation. It was proved to be one of the most sensitive parameters that may take account of both low toxicity affecting root growth as well as high toxicity affecting germination, and finally the degree of compost maturity [28]. In general, the decrease of phytotoxicity during composting results from the degradation of phytotoxic substances by microorganisms [29]. Aggelis et al. [30] proposed that: if the GI $<25$ then the substrate is characterized as very phytotoxic, if $26<\mathrm{GI}<65$ then the substrate is characterized as phytotoxic, if $66<\mathrm{GI}<100$ then the substrate is characterized as non-phytotoxic; stable and can be used for agricultural purposes as a fertilizer. According to that suggestion, the compost analyzed in our study can be deemed as phytotoxin-free, (GI values obtained ranged between $69.4 \%$ for concentration 25 and $67.7 \%$ for concentration $50 \%$ ), and safe for application as soil fertilizer.

There is no widespread consensus on the influence of organic fertilizers on crop production. Several studies have evaluated the fertilizing effects of composts and have suggested composting as one of the most appropriate techniques for producing organic fertilizers [9, 31, 32]. Composting FW has also been suggested as a valid method of transforming this waste into useful soil amendments for agricultural purposes [9]. Results of determination of the fresh and dry matter yield of leaves of ice lettuce (L. sativa L.) are presented in Table 2.

Compared to the control pot, fertilization with FW compost caused almost twofold increase in fresh matter yield and nearly $50 \%$ increase in dry matter yield of ice lettuce (L. sativa L.) leaves. The beneficial effect of compost made of FW, bark, and straw on fresh and dry matter yield of vegetables was earlier confirmed by [8, 12, 33, 34].

Soil fertilization with FW compost increased contents of macroelements in lettuce leaves (Table 3 ) by $78.6 \%$ in the case of nitrogen, by $61.8 \%$ in the case of phosphorus, by $56.3 \%$ in the case of potassium, by $44.4 \%$ in the case of sodium, and by $38.5 \%$ in the case of calcium and magnesium.

The obtained results can be compared to studies carried out by Krzebietke [35] in which the author showed the content of macroelements in the leaves of butter lettuce subjected to nitrogen fertilization to be as follows: 4.9-6.0 g/ $\mathrm{kg}$ phosphorus, 40.2-45.2 g/kg potassium, 17.1-23.0 g/ $\mathrm{kg}$ calcium, $0.8-7.3 \mathrm{~g} / \mathrm{kg}$ sodium, and $2.8-4.0 \mathrm{~g} / \mathrm{kg} \mathrm{d.m}$.
Table 3 Macroelement content in ice lettuce (Lactuca sativa L.) leaves, $\mathrm{g} / \mathrm{kg}$ d.m.

\begin{tabular}{|c|c|c|c|c|c|c|}
\hline \multirow[t]{2}{*}{ Fertilization } & \multicolumn{6}{|l|}{ Macroelement } \\
\hline & $\mathrm{N}$ & $\mathrm{P}$ & K & $\mathrm{Ca}$ & $\mathrm{Na}$ & $\mathrm{Mg}$ \\
\hline Control* & $10.03 \pm 0.72 \mathrm{a}$ & $4.24 \pm 0.33 a$ & $15.25 \pm 1.27 \mathrm{a}$ & $4.80 \pm 0.44 \mathrm{a}$ & $2.75 \pm 0.22 \mathrm{a}$ & $1.66 \pm 0.11 \mathrm{a}$ \\
\hline Compost & $17.92 \pm 1.64 b$ & $6.86 \pm 0.61 b$ & $23.84 \pm 2.24 b$ & $6.65 \pm 0.57 b$ & $3.97 \pm 0.38 b$ & $2.30 \pm 0.24 b$ \\
\hline
\end{tabular}

Bars marked with different letters differ significantly $(P<0.05)$ according to Duncan's test

Mean values of four replicates ( \pm standard deviation) are shown in the table. Data within columns that do not have common indices are significantly different at $\mathrm{p}<0.05$

*Without fertilization 
Table 4 Mass ratios between macroelements in ice lettuce (Lactuca sativa L.) leaves
Table 5 Microelement content in ice lettuce (Lactuca sativa L.) leaves, $\mathrm{mg} / \mathrm{kg}$ d.m.

\begin{tabular}{llllrl}
\hline Fertilization & \multicolumn{5}{l}{ Mass rations } \\
\cline { 2 - 6 } & $\mathrm{Ca}: \mathrm{P}$ & $\mathrm{Ca}: \mathrm{Mg}$ & $\mathrm{K}: \mathrm{Ca}$ & $\mathrm{K}: \mathrm{Mg}$ & $\mathrm{K}:(\mathrm{Ca}+\mathrm{Mg})$ \\
\hline Control* & $1.13 \pm 0.15 \mathrm{a}$ & $2.89 \pm 0.32 \mathrm{a}$ & $3.18 \pm 0.37 \mathrm{a}$ & $9.18 \pm 0.94 \mathrm{a}$ & $2.36 \pm 0.28 \mathrm{a}$ \\
Compost & $0.97 \pm 0.11 \mathrm{~b}$ & $2.89 \pm 0.35 \mathrm{a}$ & $3.58 \pm 0.42 \mathrm{~b}$ & $10.36 \pm 0.96 \mathrm{~b}$ & $2.66 \pm 0.31 \mathrm{~b}$ \\
\hline
\end{tabular}

Bars marked with different letters differ significantly $(P<0.05)$ according to Duncan's test

Mean values of four replicates ( \pm standard deviation) are shown in the table. Data within columns that do not have common indices are significantly different at $\mathrm{p}<0.05$

*Without fertilization

\begin{tabular}{llllll}
\hline Fertilization & \multicolumn{5}{l}{ Microelement } \\
\cline { 2 - 5 } & $\mathrm{Fe}$ & $\mathrm{Mn}$ & $\mathrm{Zn}$ & $\mathrm{Ni}$ & $\mathrm{Cu}$ \\
\hline Control $^{*}$ & $108.72 \pm 11.05 \mathrm{a}$ & $33.90 \pm 3.32 \mathrm{a}$ & $45.63 \pm 4.07 \mathrm{a}$ & $4.23 \pm 0.44 \mathrm{a}$ & $10.52 \pm 0.98 \mathrm{a}$ \\
Compost & $199.19 \pm 22.11 \mathrm{~b}$ & $45.99 \pm 4.66 \mathrm{~b}$ & $62.21 \pm 6.17 \mathrm{~b}$ & $6.63 \pm 0.66 \mathrm{~b}$ & $16.91 \pm 1.54 \mathrm{~b}$ \\
\hline
\end{tabular}

Bars marked with different letters differ significantly $(P<0.05)$ according to Duncan's test

Mean values of four replicates ( \pm standard deviation) are shown in the table. Data within columns that do not have common indices are significantly different at $\mathrm{p}<0.05$

*Without fertilization magnesium. The quality of the edible plant parts depends not only on the concentration of macro and microelements but also on their ratios, which may be affected not only by the species of plant but also by the proportions of cations in the fertilizers [36] (Ekholm at al. 2007). The optimal proportions between the individual elements should be higher than $\mathrm{Ca}: \mathrm{P}-2$; $\mathrm{Ca}: \mathrm{Mg}-3 ; \mathrm{K}:(\mathrm{Ca}+\mathrm{Mg})-1.6-2.2 ; \mathrm{K}$ : $\mathrm{Mg}-6$; and $\mathrm{K}: \mathrm{Ca}-2$ [37, 38]. The studies confirmed that the leaves of ice lettuce were characterized by a wider ranges of $\mathrm{K}:(\mathrm{Mg}+\mathrm{Ca}), \mathrm{K}: \mathrm{Mg}$ and $\mathrm{K}: \mathrm{Ca}$ (Table 4). Soil fertilization with compost from fish waste improved the above ratios but, simultaneously, deteriorated the Ca:P ratio.

Analyses showed an increase in contents of all analyzed microelements in ice lettuce (L. sativa L.) leaves (Table 5). The percentage increase in the concentration of the analyzed microelements ranged from $83.2 \%(\mathrm{Fe})$ to $35.7 \%(\mathrm{Mn})$ and followed the descending order: $\mathrm{Fe}>\mathrm{Cu}>\mathrm{Ni}>\mathrm{Zn}>\mathrm{Mn}$.

Radziemska and Mazur [8], who analyzed contents of heavy metals in aerial parts of corn fertilized with various composts made of FW, demonstrated the uptake of nickel, copper, and zinc by plant to depend on the chemical composition of composts and additional mineral fertilization. The concentration of macro- and micro-elements in leaves of lettuce (L. sativa L.) results from their contents in the compost in forms available to plants, and this availability depends on, among other things, $\mathrm{pH}$ value, air-water ratio, and prevalence of microorganisms [39, 40].

\section{Conclusions}

Composting of fish waste with pine bark allows for a significant reduction in the volume of fisheries by-products and waste. The stability and maturity of the compost are essential for its successful application, particularly for composts used in agriculture. However, they are not easy to define and cannot be described in a single parameter. The conducted experiments indicate the compost product to be non-phytotoxic, mature, stable, and suitable for use in agriculture. Soil fertilization with the compost from fish waste caused an increase in leaf yield of ice lettuce ( $L$. sativa $L$.) and had a significant effect on increased contents of nitrogen, phosphorus, potassium, sodium, calcium, and magnesium in leaves of the test plant. The average accumulation of microelements in ice lettuce ( $L$. sativa L.) grown in soil fertilized with the compost from fish waste followed the descending order $\mathrm{Fe}>\mathrm{Cu}>\mathrm{Ni}>\mathrm{Zn}>\mathrm{Mn}$, respectively. The proposed fish waste compost can be a useful fertilizer in agriculture.

Open Access This article is distributed under the terms of the Creative Commons Attribution 4.0 International License (http://creativeco mmons.org/licenses/by/4.0/), which permits unrestricted use, distribution, and reproduction in any medium, provided you give appropriate credit to the original author(s) and the source, provide a link to the Creative Commons license, and indicate if changes were made. 


\section{References}

1. Adamcová, D., Vaverková, M.D., Bartoň, S., Havlíček, Z., Břoušková, E.: Soil contamination in landfills: a case study of a landfill in Czech Republic. Solid Earth 7, 239-247 (2016). https ://doi.org/10.5194/se-7-239-2016

2. Ravindran, R., Jaiswal, A.K.: Exploitation of food industry waste for high-value products. Trends Biotechnol. 34, 58-69 (2016)

3. Cerda, A., Artola, A., Font, X., Barrena, R., Gea, T., Sánchez, A.: Composting of food wastes: status and challenges. Biores. Technol. (2017). https://doi.org/10.1016/j.biortech.2017.06.133

4. Garcia-Garcia, G., Woolley, E., Rahimifard, S., Colwill, J., White, R., Needham, L.: A methodology for sustainable management of food waste. Waste Biomass Valor. 8, 1-19 (2017). https://doi. org/10.1007/s12649-016-9720-0

5. Awasthi, M.K., Pandey, A.K., Bundela, P.S., Wong, J.W., Li, R., Zhang, Z.: Co-composting of gelatin industry sludge combined with organic fraction of municipal solid waste and poultry waste employing zeolite mixed with enriched nitrifying bacterial consortium. Bioresour. Technol. 213, 181-189 (2016)

6. Vaverková, M.D., Adamcová, D., Kotovicová, J., Toman, F.: Evaluation of biodegradability of plastics bags in composting conditions. Ecol. Chem. Eng. S21, 45-57 (2014)

7. Jara-Samaniego, J., Pérez-Murcia, M.D., Bustamante, M.A., Pérez-Espinosa, A., Paredes, C., López, M., Moral, R.: Composting as sustainable strategy for municipal solid waste management in the Chimborazo Region, Ecuador: suitability of the obtained composts for seedling production. J. Clean. Prod. 141, 1349-1358 (2017)

8. Radziemska, M., Mazur, Z.: Effect of compost from by-product of the fishing industry on crop yield and microelement content in maize. J. Ecol. Eng. 16, 168-175 (2015)

9. Illera-Vives, M., Labandeira, S.S., Brito, L.M., López-Fabal, A., López-Mosquera, M.E.: Evaluation of compost from seaweed and fish waste as a fertilizer for horticultural use. Sci. Hortic. 186, 101-107 (2015)

10. EC Regulation 2092/91: Regulation 2092/91/EEC of 22 July 1991 on organic production of agricultural products and indications referring thereto on agricultural products and foodstuffs. Off. J. Eur. Commun. L198, 15, 198 (1991)

11. Castro, R.S., Borges Azevedo, C.M.S., Bezerra-Neto, F.: Increasing cherry tomato yield using fish effluent as irrigation water in Northeast Brazil. Sci. Hortic. 110, 44-50 (2006)

12. López-Mosquera, M.E., Fernández-Lema, E., Villares, R., Corral, R., Alonso, B., Blanco, C.: Composting fish waste and seaweed to produce a fertilizer for use in organic agriculture. Proc. Environ. Sci. 9, 113-117 (2011)

13. Zeng, G.M., Yu, M., Chen, Y.N., Huang, D.L., Zhang, J.C., Huang, H.L., Jiang, R.Q., Yu, Z.: Effects of inoculation with Phanerochaete chrysosporium at various time points on enzyme activities during agricultural waste composting. Bioresour. Technol. 101, 222-227 (2010)

14. Sun, D., Lan, Y., Xu, E.G., Meng, J., Chen, W.: Biochar as a novel niche for culturing microbial communities in composting. Waste Manage. 54, 93-100 (2016)

15. Voběrková, S., Vaverková, M.D., Burešová, A., Adamcová, D., Vršanská, M., Kynický, J., Brtnický, M., Adam, V.: Effect of inoculation with white-rot fungi and fungal consortium on the composting efficiency of municipal solid waste. Waste Manage. 61, 157-164 (2017)

16. Belyaeva, O.N., Haynes, R.J., Sturm, E.C.: Chemical, physical and microbial properties and microbial diversity in manufactured soils produced from co-composting green waste and biosolids. Waste Manage. 32, 2248-2257 (2012)
17. Vandecasteele, B., Sinicco, T., D’Hose, T., Nest, V., Mondini, T.C.: Biochar amendment before or after composting affects compost quality and $\mathrm{N}$ losses, but not P plant uptake. J. Environ. Manage. 168, 200-209 (2016)

18. Saer, A., Lansing, S., Davitt, N.H., Graves, R.E.: Life cycle assessment of a food waste composting system: environmental impact hotspots. J. Cleaner Prod. 52, 234-244 (2013)

19. Mu, D., Horowitz, N., Casey, M., Jones, K.: Environmental and economic analysis of an in-vessel food waste composting system at Kean University in the U.S. Waste Manage. 59, 476-486 (2017)

20. Michalak, I., Chojnacka, K.: Algal compost-toward sustainable fertilization. Rev. Inorg. Chem. 33, 161-172 (2013)

21. Cui, H.-Y., Zhao, Y., Chen, Y.-N., Zhang, X., Wang, X.-Q., Lu, Q., Jia, L.-M., Wei, Z.-M.: Assessment of phytotoxicity grade during composting based on EEM/PARAFAC combined with projection pursuit regression. J. Hazard. Mater. 326, 10-17 (2017)

22. Phytotoxkit: Seed germination and early growth microbiotest with higher plants. Standard operation procedure, pp. 1-24. MicroBioTests Inc., Nazareth (2004)

23. Zhang, L., Sun, X.Y.: Addition of fish pond sediment and rock phosphate enhances the composting of green waste. Bioresour. Technol. 233, 116-126 (2017)

24. Adamcová, D., Vaverková, M.D., Břoušková, E.: The toxicity of two types of sewage sludge from wastewater treatment plant for plants. J. Ecol. Eng. 17, 33-37 (2016)

25. Valerio, M.E., Garcia, J.F., Peinado, F.M.: Determination of phytotoxicity of soluble elements in soils, based on a bioassay with lettuce (Lactuca sativa L.). Sci. Total Environ. 378, 63-66 (2007)

26. Unuofin, F.O., Mnkeni, P.N.S.: Optimization of Eisenia fetida stocking density for the bioconversion of rock phosphate enriched cow dung-waste paper mixtures. Waste Manage. 34, 2000-2006 (2014)

27. StatSoft, Inc.: Electronic Statistics Textbook. StatSoft, Tulsa (2010). http://www.statsoft.com/textbook/.

28. Rashad, F.M., Saleh, W.D., Moselhy, M.A.: Bioconversion of rice straw and certain agro-industrial wastes to amendments for organic farming systems: 1 . Composting, quality, stability and maturity indices. Bioresour. Technol. 101(15), 5952-5960 (2010)

29. Aparna, C., Saritha, P., Himabindu, V., Anjaneyulu, Y.: Techniques for the evaluation of maturity for composts. Waste Manage. (2007). https://doi.org/10.1016/j.wasman.2007.07.008

30. Aggelis, G., Ehaliotis, C., Nerud, F., Stoychev, I., Lyberatos, G., Zervakis, G.: Evaluation of white-rot fungi for detoxification and decolorization of effluents from the green olive debittering process. Appl, Microbiol, Biotechnol, 59(2-3), 353-360 (2002)

31. Han, W., Clarke, W., Pratt, S.: Composting of waste algae: a review. Waste Manage. 34, 1148-1155 (2014)

32. Piriz, M.L., Eyras, M.C., Rostagno, C.M.: Changes in biomass and botanical composition of beach-cast seaweeds in a disturbed coastal area from Argentine Patagonia. J. Appl. Phycol. 15, 67-74 (2003)

33. Illera-Vives, M., Seoane Labandeira, S., Iglesias Loureiro, L., López-Mosquerana M. E.: Agronomic assessment of a compost consisting of seaweed and fish waste as an organic fertilizer for organic potato crops. J. Appl. Phycol. 29, 1663-1671 (2017)

34. Mazur, Z., Radziemska, M.: Influence of compost from fish byproducts on nutrient supply in radish. Ecol. Chem. Eng. A 21, 231-240 (2014)

35. Krzebietke, S.: Response of butter lettuce (Lactuca sativa L.) to different forms of nitrogen fertilizers with chlorine and sulphates. J. Elementol. 13, 581-588 (2008)

36. Ekholm, P., Reinivuo, H., Mattila, P., Pakkala, H., Koponen, J., Happonen, A., Hellström, J., Ovaskainen, M.L.: Changes in the mineral and trace element contents of cereals, fruits and vegetables in Finland. J. Food Compos. Anal. 20, 487-495 (2007) 
37. Francke, A.: The effect of potassium fertilization on the macronutrient content of pepino dulce (Solanum muricatum Ait.) fruit. Acta Sci. Pol. Hortorum Cultus. 9, 51-57 (2010)

38. Wierzbicka, B., Majkowska-Gadomska, J., Nowak, M.: Concentrations of some bionutrients in parthenocarpic cucumber fruits in forced cultivation. Acta Sci. Pol. Hortorum Cultus 6, 3-8 (2007)
39. Hernández, A., Castillo, H., Ojeda, D., Arras, A., López, J., Sánchez, E.: Effect of vermicompost and compost on lettuce production. Chilean J. Agric. Res. 70, 583-589 (2010)

40. Abou-El-Hassan, S., Desoky, A.H.: Effect of compost and compost tea on organic production of head lettuce. J. Appl. Sci. Res. 9, 5650-5655 (2013)

\section{Affiliations}

\section{Maja Radziemska' ${ }^{1} \cdot$ Magdalena Daria Vaverková2 ${ }^{[0} \cdot$ Dana Adamcová $^{2} \cdot$ Martin Brtnický $^{3} \cdot$ Zbigniew Mazur $^{4}$}

1 Department of Environmental Improvement, Faculty of Civil and Environmental Engineering, Warsaw University of Life Sciences, Nowoursynowska 159, 02-776 Warsaw, Poland

2 Department of Applied and Landscape Ecology, Faculty of AgriSciences, Mendel University in Brno, Zemědělská 1, 61300 Brno, Czech Republic
3 Department of Geology and Pedology, Faculty of Forestry and Wood Technology, Mendel University in Brno, Zemědělská 1/1665, 61300 Brno, Czech Republic

4 Department of Environmental Chemistry, Faculty of Environmental Management and Agriculture, University of Warmia and Mazury in Olsztyn, Pl. Łódzki 4, 10-727 Olsztyn, Poland 